\title{
microorganisms
}

ISSN 2076-2607

www.mdpi.com/journal/microorganisms

Review

\section{Understanding Bioluminescence in Dinoflagellates-How Far Have We Come?}

\section{Martha Valiadi ${ }^{1, *}$ and Debora Iglesias-Rodriguez ${ }^{2}$}

1 Department of Evolutionary Ecology, Max Planck Institute for Evolutionary Biology, August-Thienemann-Strasse, Plön 24306, Germany

2 Department of Ecology, Evolution and Marine Biology, University of California Santa Barbara, Santa Barbara, CA 93106, USA; E-Mail: debora.iglesias-rodriguez@lifesci.ucsb.edu

* Author to whom correspondence should be addressed; E-Mail: Martha.valiadi@gmail.com or valiadi@evolbio.mpg.de; Tel.: +49-4522-763277; Fax: +49-4522-763310.

Received: 3 May 2013; in revised form: 20 August 2013 / Accepted: 24 August 2013 /

Published: 5 September 2013

\begin{abstract}
Some dinoflagellates possess the remarkable genetic, biochemical, and cellular machinery to produce bioluminescence. Bioluminescent species appear to be ubiquitous in surface waters globally and include numerous cosmopolitan and harmful taxa. Nevertheless, bioluminescence remains an enigmatic topic in biology, particularly with regard to the organisms' lifestyle. In this paper, we review the literature on the cellular mechanisms, molecular evolution, diversity, and ecology of bioluminescence in dinoflagellates, highlighting significant discoveries of the last quarter of a century. We identify significant gaps in our knowledge and conflicting information and propose some important research questions that need to be addressed to advance this research field.
\end{abstract}

Keywords: diel rhythms; functional diversity; luciferase; luciferin binding protein; gene; evolution; ecology; scintillon; predation defense

\section{Introduction}

The biological production of light or bioluminescence is a widespread phenomenon in nature. Bioluminescence is particularly predominant in the marine environment, in members of planktonic bacteria and protozoa, many invertebrates, and vertebrates with specialized light producing organs that harbor symbiotic bioluminescent bacteria (reviewed by [1]). Marine bioluminescence is mainly blue 
and, therefore, tuned to the wavelengths that travel furthest through the water. Light is produced by a chemical reaction in the presence of oxygen involving a substrate termed "luciferin" and the enzyme "luciferase". The production of these molecules and their mobilization within the cell for the production of light is thought to incur a high energetic cost. Despite that, in a remarkable example of convergent evolution, bioluminescence is estimated to have evolved independently at least forty times [1-3]. This has led to the chemistries of bioluminescent reactions being as diverse and unrelated as the organisms that produce them [2-4].

Dinoflagellates are the main eukaryotic protists that are capable of producing light $[1,5]$. Within this group, bioluminescence is present in a number of ecologically important species, many of which formblooms [6,7]. Indeed, dinoflagellates are responsible for most of the bioluminescence observed in the surface ocean [8]. Particularly when their populations are dense, disturbance of the water during the night causes bright blue bioluminescent displays that have been reported since at least $500 \mathrm{BC}$ [9] and are known to occur globally [10]. Considering the ecological importance of dinoflagellates, e.g., HABs, primary production, extensive grazing, symbiosis, parasitism (reviewed by [11]), and their prominence as producers of bioluminescence in the ocean, this fascinating phenomenon has received little attention. In this paper, we review recent progress in this topic, highlighting the major findings reported in the last quarter of a century. We also discuss findings that have led us to question key paradigms in the field or those that have revealed major gaps in our knowledge and we suggest future research directions to further our understanding of this fascinating phenomenon.

\section{Light Production in the Cell}

As with all bioluminescence systems, the one present in dinoflagellates is unique from both a cellular and molecular perspective. The production of light occurs in organelles termed scintillons [12], which contain the luciferin substrate, the luciferase enzyme (LCF) and, in some species, a luciferin binding protein (LBP) [13-16]. Scintillons are dense vesicles approximately $0.5-0.9 \mu \mathrm{m}$ in diameter [14,17] and which, during the hours of darkness, are abundantin the periphery of the cell $[18,19]$. Light is primarily produced in response to mechanical stimulation due to shear stress [20], for example upon contact with grazers or by breaking waves [21].

A cascade of cellular processes mediates bioluminescence, from sensing a stimulus to the production of light (Figure 1). The chemical reaction to produce light is $\mathrm{pH}$ dependent, requiring the acidification of scintillons. For this reason, some scintillons protrude into the acidic vacuole. The shear stress exerted on the cell membrane triggers a mechanotransduction pathway to generate an action potential across the vacuole membrane and the associated scintillons. Chen et al. [22] provided evidence that this cascade involves the activation of GTP-binding protein coupled receptors in the plasma membrane. It is, however, unknown at which stage these receptors are activated. They areunlikely to be primary sensors as the fastest G-protein signaling pathway known to date has a longer latency time than the whole transduction process in dinoflagellates [23]. Experiments by von Dassow and Latz [24] conducted using various ionic inhibitors showed that, after sensing the mechanical disturbance, the next step of the process is mediated by an increase in cytosolic $\mathrm{Ca}^{2+}$, mainly by release from intracellular stores and partially from extracellular sources. The action 
potential produced by these processes leads to an influx of protons from the acidic vacuole into the scintillons, decreasing their internal $\mathrm{pH}$ from $\sim 8$ to $\sim 6$ [25].

Figure 1. Schematic representation of part of a dinoflagellate cell, depicting the cellular processes that take place to generate a bioluminescence flash. (1) Initially, a force is exerted on the outer cell membrane. Transduction involves the activation of a G-protein coupled receptor [22] (where G stands for GTP-binding), which typically consists of a receptor (purple) comprising seven transmembrane domains and the G-protein (green) on the inner side of the cell membrane. Subsequent to transmission of the mechanical signal from the outside to the inside of the cell, the signal must be translated to an electrical signal on the vacuole membrane. (2) This is achieved by increasing the concentration of $\mathrm{Ca}^{2+}$ in the cytoplasm, mainly from sources within the cell but also from the external medium [24]. This causes the vacuole membrane to depolarize and generate an action potential. In this illustration, one of the scintillons protrudes into the vacuole and is connected to the vacuole membrane. Thus, the action potential can travel across the membrane of the scintillon. (3) This results in the activation of voltage gated proton channels, which we here assume to be concentrated on the membrane of the scintillon rather than on the remaining vacuole membrane. (4) The influx of protons from the acidic vacuole rapidly lowers the $\mathrm{pH}$ of the scintillons and activates the bioluminescence chemistry. While some of the protons may be sequestered by the production of water as a by-product of bioluminescence, the fate of the rest of these protons and the mechanism by which the scintillons return to the original $\mathrm{pH}$ values are unknown.

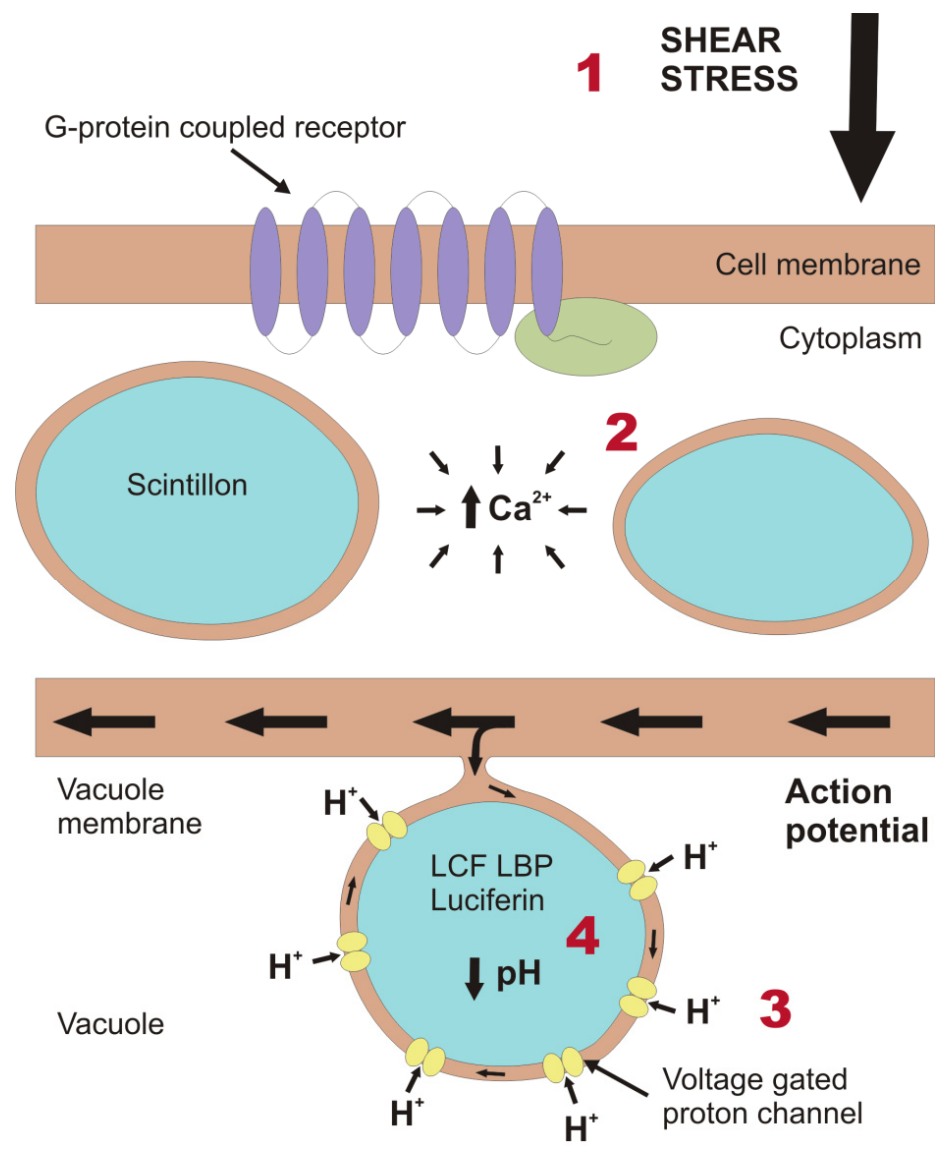


The acidification of the scintillons had long been hypothesized to be mediated by a voltage gated proton channel, and, indeed, Smith et al. [26] cloned and expressed a gene for such a unique channel that is highly proton selective, $\mathrm{pH}$ sensitive and capable of inward proton flux. Although this work was carried out on the non-bioluminescent dinoflagellate Karlodinium veneficum because of the availability of sequence data, this channel may be present in other dinoflagellates. When acidification of the scintillons is achieved it causes structural changes in LCF leading to its active conformation and making the luciferin binding sites available [27]. In species that contain LBP, this protein binds the luciferin at neutral to alkaline $\mathrm{pH}$, protecting it from autoxidation, and releases it by means of conformational change below $\mathrm{pH} 7$, at which LCF also becomes active. Luciferin is oxidized by LCF to form oxyluciferin, which results in the emission of photons (reviewed by [28,29]) in the form of a brief flash of blue light (with an approximate wavelength of $475 \mathrm{~nm}$ ). The exact details of the chemical process and the intermediate molecule that produces the light during the oxidation process are unknown. In general, the mechanotransduction pathway is remarkable as the transfer of the signal from the cell membrane to the vacuole membrane and the mobilization of all the components needed to produce a bioluminescent flash takes place in just $20 \mathrm{~ms}$.

\section{Molecular Composition and Evolution of the Bioluminescence System}

\subsection{Luciferases and Luciferin Binding Proteins}

The complex evolution of dinoflagellate bioluminescence systems has been revealed through the study of the dinoflagellate luciferase gene (lcf) which has been fully sequenced in seven genetically closely related photosynthetic dinoflagellates of the Gonyaulacales genera Alexandrium, Lingulodinium, Protoceratium, and Pyrocystis [30,31] and in the heterotrophic species Noctiluca scintillans [32]. As with nearly all dinoflagellate protein coding genes, multiple non-identical copies in tandem arrangement are present in each organism. In addition, there may be distinct gene variants encoding different isoforms of the protein and therefore rather than "genes" they can be considered gene families.

\subsubsection{Luciferase Genes of Photosynthetic Species}

The luciferase gene was first cloned and characterized from the dinoflagellate species Lingulodinium polyedrum (=Gonyaulax polyedra) [33,34] and then later found to exist in the same organization in six other species [30]. It is composed of three tandemly repeated domains (D1, D2, and D3) each consisting of a central region that is highly conserved at the amino acid level among domains and species, and encodes a catalytically active site. This region is flanked by more variable $\mathrm{N}$ - and $\mathrm{C}$-terminal regions, the roles of which are to control the $\mathrm{pH}$ response and activity of the enzyme, respectively [35,36]. Indeed, four histidine residues in the $N$-terminal regions of each domain are thought to induce the $\mathrm{pH}$-mediated conformational change that exposes the otherwise folded catalytic sites [27,36]. An $N$-terminal gene region, which shows similarities to glutathione- $S$-transferase at the amino acid level, precedes the three catalytic domains in all studied species but its function is unknown [30,31]. 
Despite the similar organization of $l c f$ in the photosynthetic species studied so far, there are species differences in the distribution of synonymous substitution rates across the gene open reading frame. While these are evenly distributed in the lcf of two Pyrocystis and two Alexandrium species, they are almost nil in the central domain regions which code for the enzyme catalytic sites in L. polyedrum and Protoceratium reticulatum [30,37]. The intergenic regions of lcf also vary considerably between species [38]. The significance of these differences among genes is unclear, especially if one assumes that the evolutionary constraints on bioluminescence are likely to be the same on the $l c f$ of all these organisms. Some of these differences may, however, relate to different regulatory elements acting in these organisms, particularly with regard to the diel cycle of bioluminescence [30,37] (explained in Section 5.1). In addition, three types of $l c f$ are known to exist in Pyrocystis lunula and one of them represents the only lcf known to contain an intron [37].

An intriguing feature of the three domain $l c f$ genes of dinoflagellates is their evolution. Sequence comparisons of individual domains from different species have shown that corresponding domains of $l c f$ are more similar in different organisms (e.g., D1 of $A$. tamarense and D1 of $P$. reticulatum) than are different domains within each organism (e.g., D1 and D2 of $A$. tamarense) [30]. This is likely to reflect an ancient triplication of a $l c f$ domain that was then carried forward during the evolution of the different photosynthetic species [30]. However, the group of photosynthetic dinoflagellates that has been studied comprises very closely related species and it is therefore likely that much more variation exists, even within photosynthetic species. For instance, a highly divergent $l c f$ exists within Ceratium digitatum [7], which is a representative of a cosmopolitan open ocean genus that has been found to dominate the bioluminescent field in the North Atlantic during late summer and autumn [39].

\subsubsection{Luciferin Binding Protein Genes of Photosynthetic Species}

The luciferin binding protein performs the important role of binding luciferin at physiological $\mathrm{pH}$, but it has received a lot less attention than luciferase. A reason for this might be that it does not exist in all bioluminescent dinoflagellates and therefore has not been considered as an essential component of the bioluminescence system. The presence of the LBP gene $(l b p)$ is well known in L. polyedrum [16,40], N. scintillans [32] and it has also been found in the transcriptomes of four Alexandrium species [41-44]. In fact, the only genus confirmed to lack expressed LBP is Pyrocystis, whose protein extracts have been screened by a universal antibody for LBP $[15,16]$. Indeed, how many of the bioluminescent dinoflagellate species utilize LBP in their bioluminescence system is currently unknown.

The only species in which $l b p$ has been well characterized is L. polyedrum. Its $l b p$ occurs as a gene family with two distinct variants with approximately $86 \%$ identity $[45,46]$, each composed of four repeat domains with little similarity between them, unlike the homologous domains lcf [32]. Both variants have been found to be expressed at equal levels [45]. The lcf and lbp of L. polyedrum show similarities such as a homologous $N$-terminal gene region [31] and a lack of introns and typical transcription promoters [46], which agrees well with their translational control through the light-dark cycle [47]. The physical structure of LBP has not yet been characterized and so it is unclear how exactly it binds luciferin, but it is thought to exist as a dimer that binds one luciferin molecule and releases it by conformational change below $\mathrm{pH} 7$ [47]. 
Recent research on dinoflagellate transcriptomes has revealed that $l b p$ mRNAs dominate the transcript pool of two Alexandrium species $[41,42,48]$. Likewise, LBP has been found to be very abundant (1\%) in the L. polyedrum proteome [47]. Transcriptome studies of A. catenella [42,48] and L. polyedrum [49] suggest that LBP is produced at a higher rate than LCF. Likewise, the concentration of LCF is estimated to be approximately 100 times lower than the value reported for LBP [50]. This could be explained if LCF can be recycled in the bioluminescent reaction while LBP is proportional to the amount of luciferin present. These results clearly indicate that, in organisms where it is present, LBP is a core part of the bioluminescence system and therefore more studies into the identity and origin of this protein are needed. This information may also explain how $P$. lunula bioluminescence operates without LBP, which is counterintuitive for a gene that seems to be central to the bioluminescence system in other species. Elucidating the crystal structure of LBP will aid in understanding how two proteins (LCF and LBP) of which corresponding gene sequences show no similarities have co-evolved to bind the same substrate and synchronize their activities to the same $\mathrm{pH}$ range.

\subsubsection{Insights from the Bioluminescence Gene of Noctiluca scintillans}

The sequence of the bioluminescence gene of $N$. scintillans obtained by Liu and Hastings [32] was the first representative of a heterotrophic dinoflagellate and outside the order Gonyaulacales, the focus of all previous work. This proved to be a significant milestone in understanding the extreme diversity of $l c f$ in dinoflagellates. The $l c f$ in $N$. scintillansis unique as it consists of only one domain which is shorter than that of photosynthetic species and is attached to $l b p$ as a single hybrid gene (Figure 2). Its $N$-terminal gene region lacks any sequence similarity and is much shorter than that of photosynthetic species. Additionally, the $l c f$ domain is shorter by 60 amino acids at the $N$-terminal than the $l c f$ domains of photosynthetic species and is thus missing three of the four histidines that are thought to be responsible for $\mathrm{pH}$ regulation. Nevertheless, the $\mathrm{pH}$ regulation remains. Despite these major structural differences, both the functionally relevant central part of the $l c f$ domain and $l b p$ domain retain sequence similarity at the amino acid level to L. polyedrum. The origin of this hybrid gene in $N$. scintillans has been difficult to interpret [32] and its significance is controversial [51,52]. The triplication of $l c f$ domains in the seven studied photosynthetic dinoflagellates is thought to have occurred in their common ancestor before their divergence [30]. Therefore, if $N$. scintillans is a primitive dinoflagellate as suggested by many phylogenies, the lcfllbp could have undergone fission giving rise to the separate genes in photosynthetic species [32]. However, if it is a more recently derived lineage, the separate $l c f$ and $l b p$ could have fused in this species, with reduction of $l c f$ to a single domain [32]. The order of these events is important in understanding the evolution of these proteins in relation to different selection pressures that may require differential regulation pathways of these genes. The most recent phylogenetic analysis of $N$. scintillans and other noctilucoids based on ribosomal genes, suggests that it is indeed a primitive dinoflagellate species [53]. However, a phylogeny based on a combined analysis of ribosomal and protein-coding genes has questioned this conclusion [54]. In this case, N. scintillans may have acquired its bioluminescence gene by horizontal transfer and subsequent modification from another dinoflagellate, which is consistent with bioluminescence being absent in other noctilucoid dinoflagellates. Regardless of which scenario is true, 
the triplication of the separate $l c f$ in photosynthetic species has been suggested to confer an advantage by tripling the catalytic capacity that can be achieved within the scintillons without a tripling of their protein content that would increase their osmotic pressure [33]. It is therefore important to ascertain whether evolution is selecting for higher bioluminescence capacity within each scintillon. The answers to these questions will come with complete sequencing of bioluminescence genes from other species, especially including representatives of taxonomic groups that are distinct from the ones already sequenced, for example, Ceratium and Protoperidinium spp. The key questions that remain to be answered are: (1) is there an $l c f$ with two domains? (2) which species contain $l b p$ ? (3) when did $l b p$ become part of or was lost from $l c f$ ?

Figure 2. A schematic representation of the different LCF and LBP structures labeled with amino acid positions and the two scenarios for their evolution [30,32]. Lingulodinium polyedrum LCF represents the photosynthetic dinoflagellates in general [30]. The three non-identical repeat domains of L. polyedrum LCF (different shades of blue) are each 377 amino acids long with 150 amino acids in the central regions that encode the catalytic sites (patterned) and retain higher sequence similarity. The single LCF domain of $N$. scintillansis most similar to the second domain of L. polyedrum LCF. The LBP domain in N. scintillans is structurally equivalent to that in L. polyedrum, both consisting of four repeat domains. In both organisms, LCF is preceded by an $N$-terminal gene region which is similar in the LCF and LBP of L. polyedrum (red) but not in $N$. scintillans (orange). Two potential scenarios of how these gene structures arose are shown. In the gene fission scenario (black line), the N. scintillans gene split and the LCF domain underwent successive duplications. In the gene fusion scenario (brown lines), the second domain of LCF was excised (e.g., by splicing) and fused with LBP in N. scintillans.

L. polyedrum LCF

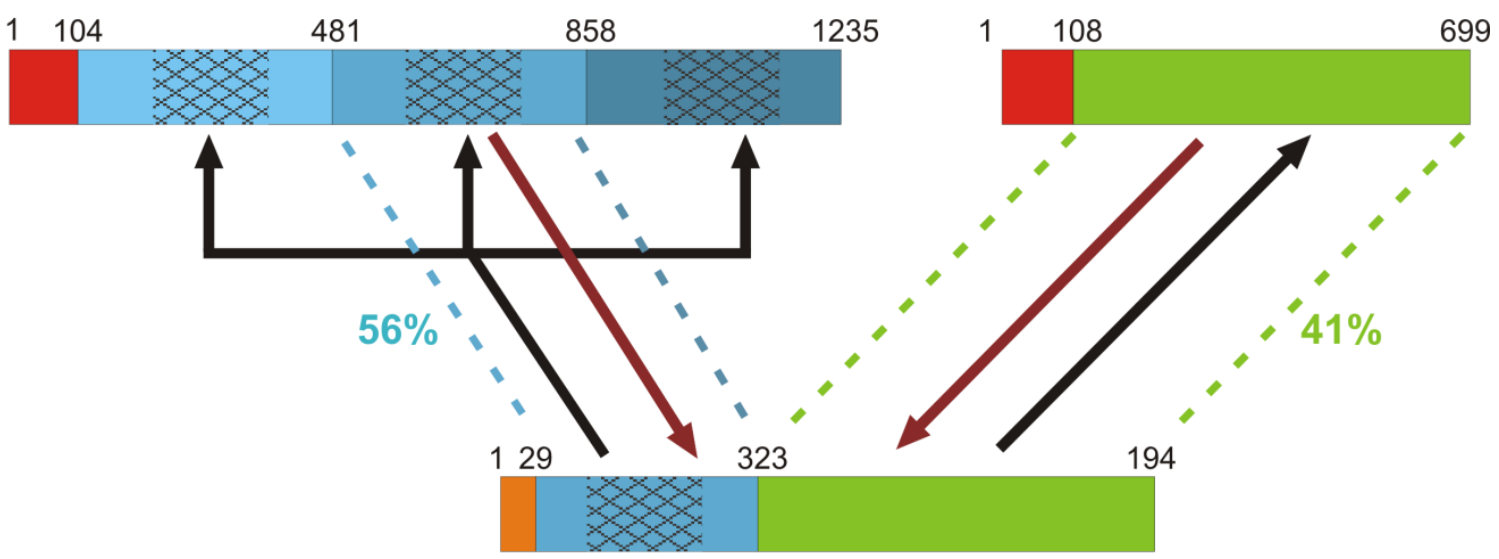

N. scintillans LCF/LBP

\subsection{The Elusive Luciferin}

The structure of the luciferin molecule has only been characterized in P. lunula due to the relative ease of extraction because cells lack a theca and because they contain approximately 100 times more 
luciferin that L. polyedrum [16]. The structure of $P$. lunula luciferin was fully characterized by Nakamura et al. [55] as a linear tetrapyrrole with similarity to chlorophyll a. This molecule exhibits a characteristic blue fluorescence $(475 \mathrm{~nm})$ when irradiated with UV light, a feature that is also used to visualize scintillons in cells by epifluorescence microscopy. However, the fluorescence of the molecule ceases when it has been oxidized either by LCF or by air. A study with amino acid tracers has confirmed the intracellular production of luciferin in P. lunula [56] and Topalov and Kishi [57] suggested that luciferin is a product of chlorophyll degradation by means of photooxidation.

It is generally assumed that all dinoflagellate luciferins are the same as in P. lunula because its luciferin has been shown to cross react with the LCF of all other bioluminescent dinoflagellates species [16,58]. This is also the case with the euphasiid shrimp (krill) Euphasia superba, the LCF of which can also cross-react with $P$. lunula luciferin. Indeed, the luciferin of $E$. superba is very similar to that of $P$. lunula but it is more closely related to chlorophyll c [57], presumably obtained from its prey. A similar hypothesis for the dietary acquisition of chlorophyll for luciferin production has been put forward for the heterotroph N. scintillans [32]. However, a recent study on another heterotrophic dinoflagellate, Protoperidinium crassipes, showed that bioluminescence intensity persisted after the cells were cultured for one year on rice flour, hence, luciferin could not have been synthesized from chlorophyll but rather must have been produced endogenously [59]. It is important to note that while luciferins and LCF cross-react even between phylogenetically very distant organisms such as dinoflagellates and krill, their LCF exhibits completely different characteristics. The LCF of euphasiids has not been cloned but its molecular weight is $600 \mathrm{kDa}$ [60] in contrast to $135 \mathrm{kDa}$ of the LCF in photosynthetic dinoflagellates [30,33]. In addition, euphausiid LCF exhibits much slower kinetics than dinoflagellate LCF. Therefore, it seems that bioluminescence systems exhibit some degree of flexibility in the reactants used to produce light. Additionally, the hypothesis that the origin of luciferin is photo-oxidated chlorophyll [57] is only plausible for P. lunula, which maintains its luciferin throughout the light-dark cycle. Fluorescent luciferin only appears in L. polyedrum at the onset of the dark-phase [13] thus, its formation cannot be explained by the photo-oxidation mechanism. Therefore, it is likely that more than one mechanism is responsible for the production of luciferin, even in photosynthetic species with closely related LCFs.

\section{Diversity of Bioluminescent Species}

Several bioluminescent species are cosmopolitan in both coastal and open ocean regions and include important heterotrophs (e.g., Noctiluca and Protoperidinium) and toxic (e.g., Alexandrium), or generally harmful species (e.g., Noctiluca, Lingulodinium, and Ceratium). Although bioluminescent species have been reported to occur in 17 dinoflagellate genera (compiled by [6]) recent work in our lab [7] clarified some ambiguities that stemmed from inaccurate field observations and confusion from inherent variation in bioluminescence among clonal strains. Key genera such as Ceratium and Protoperidinium have not been studied in enough detail to enable conclusive reporting of their bioluminescent members, but as a guide, Table 1 indicates which genera are dominated by bioluminescent species and those in which bioluminescence is less predominant.

A lot of effort has been put into characterizing bioluminescent dinoflagellate species. An obvious reason for this is that it aids the classification of cells identified by microscopy into bioluminescent and 
non-bioluminescent groups. One purpose of this information can be to determine the extent to which various taxa contribute to the total bioluminescence elicited from a body of water (e.g., [39,61]). A further purpose can be to investigate the seasonality of bioluminescent dinoflagellate populations in time series, especially in relation to the total dinoflagellate populations. Another important use of this information is in investigating potential evolutionary similarities of bioluminescent species, or how bioluminescence may have been acquired and lost among and within different dinoflagellate lineages.

Table 1. Genera with reported bioluminescent species from Marcinko et al. [62], Poupin et al. [6], and Valiadi et al. [7]. The numbers of species within each genus is according to the taxonomically accepted species listed in Algae Base [63]. The question mark indicates that the report is anecdotal and not confirmed.

\begin{tabular}{cccc}
\hline $\begin{array}{c}\text { Order } \\
\text { Family }\end{array}$ & Genus & $\begin{array}{c}\text { No. of reported } \\
\text { BL species }\end{array}$ & $\begin{array}{c}\text { Total no. of } \\
\text { species in genus }\end{array}$ \\
\hline Ceratiaceae & Gonyaulacales & 77 \\
Goniodomaceae & (Neo)ceratium & 4 & 31 \\
& Alexandrium & 7 & 1 \\
Cladopixidaceae? & Pyrodinium & 1 & 3 \\
Ceratocoryaceae & Ceratocorys & 1 & 11 \\
Gonyaulaceae & Gonyaulax & 1 & 72 \\
& Lingulodinium & 11 & 2 \\
Pyrocystaceae & Pyrocystis & 1 & 16 \\
Pyrophacaceae & Fragilidium & 4 & 5 \\
& Pyrophacus & 1 & 4 \\
\hline & & Gymnodiniales & \\
\hline Gymnodiniaceae & Polykrikos & 2 & 1 \\
\hline \multicolumn{5}{c}{ Noctilucaceae } & Noctiluca & 1 & 295 \\
\hline
\end{tabular}

The two largest genera of bioluminescent dinoflagellates both in terms of size and range, Ceratium and Protoperidinium, contain a very low proportion of bioluminescent representatives (Table 1). Presumably, this is because they are notoriously difficult to maintain in culture and, therefore, their taxonomic classification has not been studied in depth, especially with molecular markers. Indeed, dinoflagellate species complexes that were considered as one genus have often been re-classified after extensive investigations as separate genera, for example, the genus Gonyaulax from which Lingulodinium, Alexandrium, and Protoceratium were defined. Tracing the lineage specific evolutionary pathways of bioluminescence will greatly benefit from detailed studies of species/strains belonging to these two ecologically important genera. This will be important as both Ceratium and Protoperidinium are highly represented in natural bioluminescent dinoflagellate populations [39]. Finally, although the ability to produce light is exhibited by phylogenetically disparate dinoflagellate taxa, it is dominated by the Gonyaulacales, suggesting that either, both the genes and cellular 
machinery for bioluminescence were born within this group, or they were acquired from a less conspicuous ancestor.

\section{Factors Affecting the Intensity of Bioluminescence Emissions}

The measurement of the bioluminescence signature in a dinoflagellate culture or a single cell reveals a complex signal whose features vary from species to species and cell to cell, time of day, and the physiological status of the cell. This section describes some of the most common factors that affect the characteristics of bioluminescence signatures in different organisms with their unique life histories.

\subsection{Diurnal Rhythms of Bioluminescence}

Most bioluminescent dinoflagellates display a diurnal rhythm in bioluminescence intensity, being much brighter in the night than in the day, when it is almost negligible. The two main mechanisms underlying this variation are the regulation of bioluminescence at the molecular and cellular level by a circadian clock and/or photoinhibition of bioluminescence in the day.

In photosynthetic dinoflagellates, bioluminescence exhibits a diurnal rhythm controlled by an endogenous circadian clock. This makes bioluminescence almost undetectable in the day and brightest at night. The regulation of the bioluminescence circadian rhythms varies significantly in the two dinoflagellate species (L. polyedrum and P. lunula) that have been extensively studied (reviewed in depth by [64]). In L. polyedrum, the quantity of LCF and LBP is translationally regulated, while mRNA levels of both genes remain stable throughout the light-dark cycle $[15,65,66]$. It has been suggested that this process is mediated by a repressor protein which binds to the 3 ' untranslated region of the lcf mRNA [67], although this has been disputed [68]. The LCF, LBP, luciferin, and the scintillons themselves are destroyed at dawn and then begin to be resynthesized at dusk; they peak in quantity approximately four hours into the night when they reach amounts that are 10 times higher than in the day $[13,18,50,69]$. In contrast, $P$. lunula regulates its bioluminescence in a completely different way. The number of scintillons and their luciferin and LCF content, as well as $l c f$ mRNA, do not vary [15,37]. Instead, the scintillons are relocated interchangeably with the chloroplasts to modulate bioluminescence intensity, placing the scintillons at the periphery of the cell during the night but near the center of the cell during the day to prevent their stimulation [19].

Besides a circadian rhythm, bioluminescence intensity is diminished in the day by photoinhibition. This is likely to occur in all dinoflagellates as it has been extensively documented in both photosynthetic and heterotrophic species [70-76]. Only two exceptions have been reported, one being N. scintillans [76] and the other being a natural population of Protoperidinium antarcticum [77], which is in disagreement with observations in other Protoperidinium species [73,76]. The majority of bioluminescent species are most sensitive to blue light, which reduces their sensitivity to mechanical stimulation, irrespective of the amount of LCF or luciferin contained in the cell $[70,73,74,78]$. Neither the mechanism by which photoinhibition takes place, nor the identity of the receptor of the inhibiting light, has been found. Nevertheless, photoinhibition of bioluminescence is considered an important evolutionary adaptation to tune bioluminescence to the times when it is visible and minimize unnecessary energy expenditure. 
The molecular regulation of circadian rhythms has received a lot more attention than photoinhibition. Photoinhibition is rather more universal in bioluminescent dinoflagellates than are circadian rhythms, since many heterotrophic species such as Protoperidinium do not show circadian regulation of their bioluminescence but do show photoinhibition [76,79]. The importance of the photoinhibition of bioluminescence in nature has been shown in in situ mixed populations containing both photosynthetic and heterotrophic dinoflagellates $[61,79,80]$, whereas circadian rhythms may be important when the bioluminescent population is dominated by photosynthetic species (e.g., [61,81]). Nevertheless, photoinhibition is ecologically more relevant than circadian rhythms because natural dinoflagellate populations are inevitably exposed to natural day-night cycles in the euphotic zone.

A much less investigated phenomenon that also exhibits circadian control is spontaneous bioluminescence. This has been recorded in L. polyedrum [82], P. lunula [81,83], Pyrodinium bahamense [81], and Ceratocorys horrida [84]. Lingulodinium polyedrum emits spontaneous flashes at the beginning of the dark phase and a continuous glow at the end of the dark phase. Pyrocystis lunula and $P$. bahamense emit spontaneous flashes during the whole dark phase but do not generate significant glow. A constant background low-level light emission has been seen in all three species during dark phase. Ceratocorys horrida emits spontaneous flashes throughout the dark phase and a glow at the end. Spontaneous flashing and glowing and background low level emissions are likely to represent biochemical and cellular processes that could shed light on the endogenous (i.e., not externally stimulated) function of bioluminescence.

\subsection{Species-Specific Bioluminescence Signatures}

There seem to be considerable differences in flash characteristics among species. For example, the duration of a flash varies significantly, between $80 \mathrm{~ms}$ in $N$. scintillans [85], 130-150 $\mathrm{ms}$ in L. polyedrum [84] and $500 \mathrm{~ms}$ in Pyrocystis fusiformis [86]. In addition, the brightness of the emitted light differs considerably among species, ranging from $10^{7}$ photons per cell in Gonyaulax excavata (synonym Alexandrium tamarense) [87] to $10^{9}$ photons per cell in Pyrocystis noctiluca [88]. These differences could be due to a number of reasons. An important factor is thought to be cell size, with larger cells emitting more light [89], because the number of scintillons a cell can contain is proportional to its size. For example, cells of $L$. polyedrumin the dark phase contain on average 320 scintillons per cell [18], while the larger Noctiluca scintillans contains 100,000-200,000 scintillons per cell [90,91]. The amount of available luciferin can also vary by 100 -fold [16] and it is probably related to scintillon number. Furthermore, the number of scintillons stimulated in one flash has been found to be as few as $5 \%$ in N. scintillans [85]. Likewise, only a small fraction of the molecules involved, around $15 \%$ in P. fusiformis [86], are used up in one flash. In addition, the sensitivity of each species to mechanical stimulation is variable [92]. It is also important to note that in cultures it is inherently difficult to obtain ecologically-relevant measurements of species-specific flash intensity as culture conditions tend to diminish bioluminescence over time $[93,94]$. For example, not all cells within a monoclonal culture contain scintillons and those that do may have varying numbers [95]. Intraspecific variation in bioluminescence presence/absence and intensity has also been observed in isolates from a single natural population of $P$. lunula [96]. Therefore, the characteristics of bioluminescence produced 
by each species, or even every cell, can differ significantly because of several simultaneous endogenous controls.

\subsection{Physiological State}

The intensity of bioluminescence can be affected by the physiological status of the cells and by environmental factors. Bioluminescence may diminish when heterotrophic cells are starved [73,76,97] and when cultures of photosynthetic species become nutrient depleted [70,98]. Furthermore, combined effects are known in Protoperidinium depressum in which the bioluminescence system became even more sensitive to photoinhibition after a period of starvation [73]. However, Latz and Jeong [99] found that bioluminescence correlated with feeding frequency rather than growth rate in $P$. divergens and $P$. crassipes and that cells continued to invest energy in bioluminescence despite being unable to grow. In photosynthetic species, the response of bioluminescence intensity to limitation by different nutrients has not been explicitly assessed. However, a recent study of the transcriptome of Alexandrium fundyense showed that the expression of $l b p$ was higher in phosphate limitation than in nitrate limitation [41].

Bioluminescence can also be photoenhanced, whereby the light emitted in the dark is proportional to the total amount of light received in the preceding light phase. This has been reported in L. polyedrum cultures [75], in laboratory cultures and natural populations of Ceratium fusus [100], and in natural populations dominated by Gonyaulax species [61]. However, the biochemical and physiological processes leading to this phenomenon have not been explored. Specifically, it is unclear whether the changes in bioluminescence intensity are due to changes in the sensitivity of the cells to mechanical stimulation or to differences in the production of substrates for bioluminescence under different irradiance regimes. Investigating these questions may shed light on the reciprocal interactions between bioluminescence and other photo-regulated metabolic pathways.

\section{The Function of Bioluminescence in Dinoflagellates}

The functions of marine bioluminescence have mainly been studied in deep-sea megafauna and in bacteria, where it plays a range of important roles, including oxygen defense, predator avoidance, camouflage and courtship (reviewed by [1,2]), in various bioluminescent organisms. However, the function of bioluminescence in dinoflagellates has been less extensively assessed and the theoretical concepts that have been put forward are only supported by limited experimental evidence.

Dinoflagellate bioluminescence is proposed to act as defense against predation (recently reviewed by Marcinko et al. [62]). It is well known that shear stimulates dinoflagellate bioluminescence [20,92], for example, due to proximity or contact with zooplankton. An example of this interaction is shown in Figure 3. Early studies by Esaias and Curl [101] and White [102] showed that the higher the bioluminescence intensity of the dinoflagellate Gonyaulax sp. (by using cells at different stages of the dark phase) the fewer the cells consumed by the copepod genera Acartia and Calanus, most likely due to the disruption of the copepods' swimming and feeding behavior by bioluminescent flashes [103]. Photophobic responses of marine zooplankton to artificial flashes of light have been reported in several studies [103-105] and the authors have suggested that bioluminescence could confer an evolutionary 
advantage to dinoflagellates by reducing predation pressure directly through startling and repelling their predators.

Figure 3. Image sequence from a video of bioluminescent dinoflagellates flashing in response to stimulation by copepods. The time from the beginning of the image sequence is indicated on each frame. Three copepods $(\mathrm{C} 1-\mathrm{C} 3)$ collide and rapidly swim away from each other. During these fast swimming bursts, the dinoflagellates are stimulated to bioluminesce, although it is not possible to discern whether this is due to the copepod swimming current or to direct contact. Bioluminescence is seen to develop and diminish in the scintillons of two cells of Pyrocystis noctiluca $(\mathrm{Pn})$ and a Pyrocystis fusiformis (Pf), which is pulled into the field of view at $160 \mathrm{~ms}$ by the copepod swimming current. The video was filmed by Ammonite Films at the National Oceanography Centre - Southampton. Filming was done under an inverted microscope at $10 \times$ magnification. The outline was captured using infrared light and bioluminescence was captured by a blue sensitive camera.
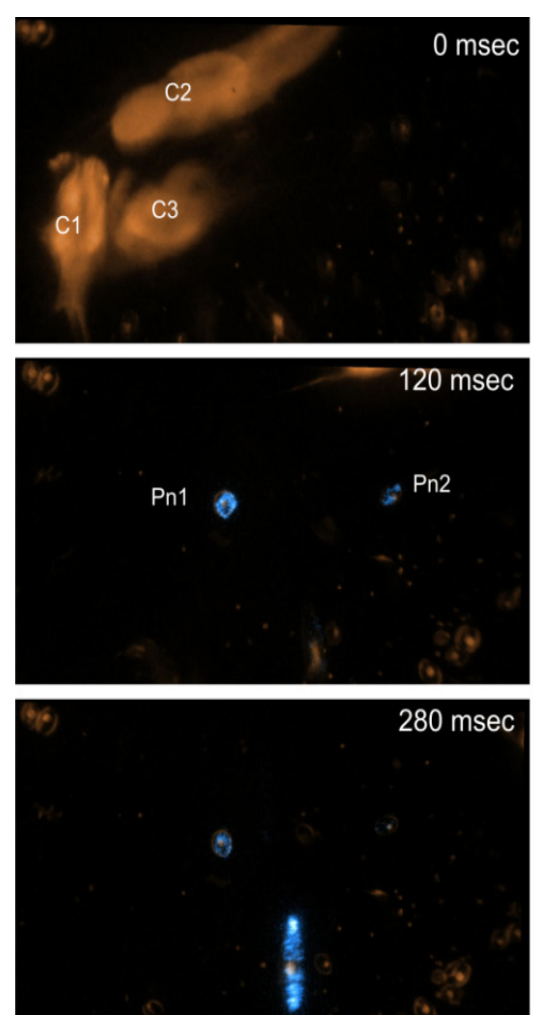
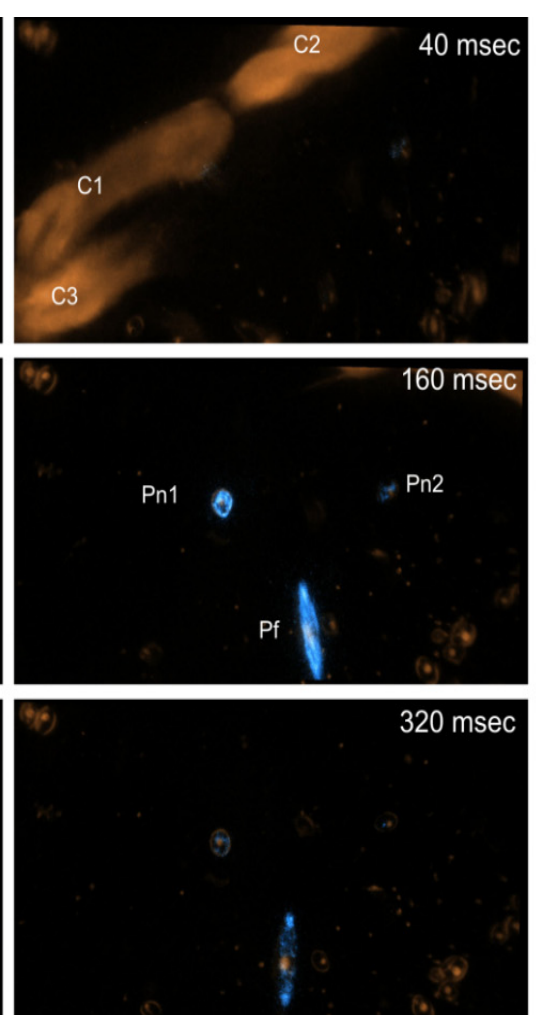
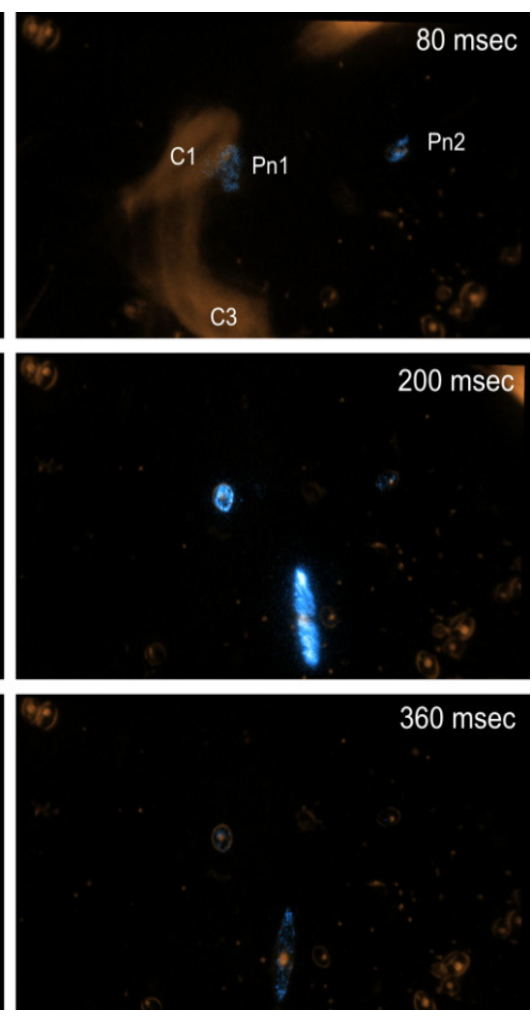

A widely accepted theory is that bioluminescence protects dinoflagellates indirectly by acting as a "burglar alarm" [106]: when a flash is stimulated by contact with a grazer, it will attract a higher-level predator that will then consume the grazer. This theory received a lot of attention in the early 1990s with several studies seeking to demonstrate it experimentally. In general, these experiments have compared predation rates on zooplankton by higher-level predators in the presence of bioluminescent dinoflagellate cells whose natural bioluminescence intensity could be varied by using cells at different phases of their light-dark period. The findings of the two key studies in the literature agreed despite using very different experimental communities, one containing the dinoflagellate L. polyedrum, the copepod Tigriopus japonicus and three spine sticklebacks [107], and the other containing the dinoflagellate P. fusiformis, the mysid Holmesimysiscostata and the midshipman fish Porichthys 
notatus [108]. In both studies, the authors postulated that even if the dinoflagellate which flashes (i.e., the bioluminescent genotype) dies, the population as a whole will still benefit because blooms form asexually and therefore the organisms are genetically highly similar. This would indeed be the case in asexually reproducing bloom-forming populations composed of genetically similar individuals. However, there is significant intraspecific variation in bioluminescence intensity in natural populations [96] and bioluminescence does not occur only in bloom-forming dinoflagellates.

Although all these studies have shown important elements of bioluminescence effects on two trophic levels and claim that dinoflagellates can benefit from the reduced number of grazers, they present two significant experimental caveats. First, dinoflagellate densities at the beginning and end of each experiment have not been reported [107,108] mainly because the adverse effect of bacterial contamination incurred by the introduction of a large animal could not be assessed [107]. Second and foremost, none of these experiments have used organisms that co-occur in nature. For example, Mesinger and Case [108] used mysids and fish from Santa Barbara, California, but P. fusiformis does not occur in this region. Rather, in this experiment, the use of L. polyedrum, which is endemic to Southern California's coast, would have been more ecologically relevant. In addition, even if organisms from the same area were used, they may be separated seasonally and therefore may not encounter each other naturally. It is entirely plausible that this swimming behavior of zooplankton in response to dinoflagellate bioluminescence may lead to zooplankton exclusion zones from areas in the water column with high densities of bioluminescent dinoflagellates. This could even benefit other organisms that may be mixed within the dinoflagellate population, including other dinoflagellates.

The limited understanding of the ecological significance of bioluminescence in dinoflagellates partly stems from the lack of in situ studies on these organisms. Planktonic bioluminescence has been explored in the coastal and open oceans only by measuring total bioluminescence of both dinoflagellates and zooplankton using bathyphotometers. There have been two major field programs of this type, one in the Sargasso Sea (Biowatt- $[80,109,110]$ ) and one in the North Atlantic (Marine Light Mixed Layers-[39,111]), that have directly investigated relationships between stimulated bioluminescence and the bioluminescent organisms present with the overarching aim of predicting bioluminescence in the water column (recently reviewed by [62]). As optical bioluminescence measurements are in discriminatory to the array of organisms that produce light and because there are temporal changes in the contributions of dinoflagellates and zooplankton to the total photon budget, these studies have not been able to show a consistent relationship of bioluminescence to any environmental factors. Furthermore, dinoflagellate bioluminescence signatures can be affected by several parameters as outlined in Section 5 and are thus difficult to use in estimating the abundance of bioluminescent dinoflagellate cells. Therefore, in order to explore the distribution and composition of bioluminescent dinoflagellate populations in the ocean, an alternative approach to optical measurements is needed. A better characterization of bioluminescent species or their molecular detection in the field may be helpful in this direction [7,112].

A metabolic or cell physiological role for bioluminescence has never been explored. A surprising finding was made by Erdner and Anderson [41] in a study of the transcriptome of Alexandrium fundyense which showed that the expression of $l b p$ was higher under phosphate limitation than under nitrate limitation, therefore showing the different relationships of bioluminescence to these two key metabolic processes. The importance of bioluminescence, particularly of LBP, to the life of 
the cell has been documented in several dinoflagellate transcriptome studies. Jaeckisch et al. [44] reported that $l b p$ was the eighth most expressed gene in Alexandrium ostenfeldii. Uribe et al. [42] found that $l b p$ was the most highly expressed gene in $A$. catenella representing $3 \%$ of the total expressed sequence tags, whereas genes involved in core functions like cell cycle and metabolism were expressed at lower levels. Similar results were reported by Toulza et al. [48] using a different strain of A. catenella. A main difference between these studies was that $l c f$ expression was ranked either second [42] or sixteenth [48]. Despite this discrepancy, which may be due to differences in the employed sequencing technology, time of sampling, or due to culturing effects (e.g., mutations leading to loss of expression from some $l b p$ copies), both studies agree that lcf expression is high. As mentioned previously, the high expression level of a bioluminescence protein has also been reported for L. polyedrum [47]. Despite these striking findings, not a single metabolic physiological study on bioluminescence has been reported.

A recent hypothesis for the original function of bioluminescence has been put forward by Wilson and Hastings [29]. In their "oxygen defense" hypothesis they argue that bioluminescence systems evolved in response to low oxygen levels during the time between the great oxidation event ( 2 billion years ago), when photosynthesis evolved, and the Cambrian explosion (500-550 million years ago). Wilson and Hastings suggest that because all bioluminescence systems consume oxygen, they detoxified organisms from oxygen, with light being a simple by-product. Bioluminescence would have then acquired a different functional role when antioxidant pathways, such as superoxide dismutases and catalases, became widespread with increasing oxygen levels. Their hypothesis is mainly based on the bioluminescence systems of bacteria and fireflies but it is indeed plausible for the other bioluminescent organisms as well. In dinoflagellates, this scenario would require that the early chemistry was not $\mathrm{pH}$ regulated since lowering the $\mathrm{pH}$ to "activate" LCF and LBP can currently only take place in the scintillons. These are not thought to be independent vesicles but would have rather evolved later to tune bioluminescence to specific responses like mechanical stimulation. Such a scenario would also mean that every trace of bioluminescence has been eliminated from basal dinoflagellate lineages. At present there is not enough evidence to evaluate this hypothesis. Progress in both lcf sequencing and characterization of luciferin in more organisms is needed to explore the likelihood of the "oxygen defense" hypothesis in dinoflagellates. However, regardless of whether or not this hypothesis holds true, bioluminescence in dinoflagellates will serve an alternative function in the present day as it is not known to provide them with any advantage in fighting oxidative stress.

\section{Conclusions and Future Directions}

Bioluminescence is an innovation in the life of many dinoflagellates species with substantial visual, ecological and cellular effects and is, therefore, an integral part of their lifestyle. Much progress has been made in recent years towards understanding this process, particularly regarding the cellular mechanisms, circadian rhythms and the molecular evolution of bioluminescence in dinoflagellates. However, in this review we have highlighted the infant status of our knowledge of the evolution, mechanism and controls on bioluminescence and raised several new questions that need to be investigated. 
The cellular mechanisms of bioluminescence and the molecular evolution of $l c f$ and $l b p$ are fairly well characterized. The greatest highlights of the last 25 years have been the sequencing of $l c f$ from several species, especially $N$. scintillans, the characterization of $P$. lunula luciferin and significant progress in our understanding of the cellular components and mechanotransduction pathway that induce the production of light. The collation of data on bioluminescent species and the first ecological experiments involving bioluminescent dinoflagellates have also resulted in significant insight into the topic. However, important questions about the identity of luciferin and the evolutionary processes that have led to the current configuration of $l c f$ and $l b p$ have arisen in recent years. One research priority is to determine the structure and origin of luciferin in bioluminescent dinoflagellate species other than $P$. lunula, preferably a heterotroph cultured without photosynthetic prey and a species that is known to contain LBP such as L. polyedrum. This will capture any potential variation in the structure and origin of luciferin in distinct groups and provide important insights into how the bioluminescence system may be linked to other metabolic functions. Further characterization of LBP, especially its structure and distribution within dinoflagellates is needed to understand why this protein is so abundant in many bioluminescent species and how it has co-evolved with the rest of the bioluminescence system. Full sequences of $l c f$ from a variety of organisms are needed for two reasons: to enable tracing the evolutionary origin of bioluminescence and to assess how the composition of the bioluminescence system has changed over time in relation to differential regulatory requirements or selection pressures on each gene and its variants. For example, L. polyedrum is $\sim 30$ times smaller and contains at least 300 times fewer scintillons than $N$. scintillans $[18,90,91]$ and yet, its bioluminescence intensity is only $\sim 200$ times less [76,93]. This is consistent with the proposal by Liu and Hastings [30] that the triplicate structure of LCF allows cells to triple the catalytic capacity within the scintillons without increasing the osmotic pressure. It also means that smaller cells can achieve the highest possible bioluminescence intensity relative to their scintillon carrying capacity, suggesting that selection acts towards higher bioluminescence in these populations.

Bioluminescence is difficult to place in an ecological context because its function is not fully understood. Indeed, the function of bioluminescence has been investigated much less than any other topic in the field. The predator defense hypotheses have not yet been sufficiently investigated. The "oxygen defense", if true, may explain how bioluminescence initially arose and evolved before it developed an effect on another group of organisms that could be selected for. However, it does not imply that bioluminescence has the same function in the modern ocean. Also, the environmental regulation of bioluminescence remains an open question. A good place to start would be to investigate changes in bioluminescence, gene/protein expression and luciferin content in response to changing environmental conditions, such as nutrient availability, that are frequently encountered in nature.

As with all functional traits of an organism, it is more realistic to investigate the function of bioluminescence in its natural context. While the complexity of natural ecosystems makes this task difficult, observations in nature can reveal the true selection pressures and ecological dynamics of bioluminescence. Blooms that frequently occur in coastal ecosystems can provide a natural laboratory for such studies and desired measurements can be easily incorporated into existing time series monitoring programs (e.g., those for monitoring HABs). Measurements of population structure in relation to bioluminescence at the molecular and phenotypic level, followed by linking to observations of co-occurring organisms, particularly non-bioluminescent dinoflagellates, zooplankton and potential 
prey, nutrients levels and irradiance levels would be a starting point to investigate the function and ecology of dinoflagellate bioluminescence.

Since ecology and evolution are inseparable, integrated studies of gene evolution and regulation with new clues on the environmental factors and ecological interactions that regulate bioluminescence will help us understand the role of this incredible functional innovation in the life of dinoflagellates.

\section{Acknowledgments}

We are very grateful to J. Woodland Hastings for valuable comments on an earlier draft of this manuscript and to Peter von Dassow for insightful discussion on the cellular mechanisms of bioluminescence. We also thank Martin Dohrn from Ammonite Films for providing the video and images of individual frames used in Figure 3. This research was financially supported by the Luminescence and Marine Plankton project (Defence Science and Technology Laboratory and Natural Environment Research Council joint grant scheme proposal, ref. 1166, awarded to John T. Allen and DIR) and the Office of Naval Research (ONR award number N000140410180, awarded to DIR). We also thank colleagues and two anonymous reviewers whose comments helped improve this manuscript.

\section{Conflicts of Interest}

The authors declare no conflict of interest.

\section{References}

1. Haddock, S.H.D.; Moline, M.A.; Case, J.F. Bioluminescence in the sea. Ann. Rev. Mar. Sci. 2010, 2, 443-493.

2. Widder, E.A. Bioluminescence in the ocean: Origins of biological, chemical, and ecological diversity. Science 2010, 328, 704-708.

3. Wilson, T.; Hastings, J.W. Bioluminescence. Annu. Rev. Cell Dev. Biol. 1998, 14, 197-230.

4. Hastings, J.W. Chemistry and control of luminescence in marine organisms. Bull. Mar. Sci. 1983, 33, 818-828.

5. Widder, E.A. Marine bioluminescence. Biosci. Explain. 2001, 1, 1-9.

6. Poupin, J.; Cussatlegras, A.S.; Geistdoerfer, P. Plancton Marin Bioluminescen; Rapport Scientifique du LOEN: Brest, France, 1999; p. 83.

7. Valiadi, M.; Iglesias-Rodriguez, M.D.; Amorim, A. Distribution and genetic diversity of the luciferase gene within marine dinoflagellates. J. Phycol. 2012, 48, 826-836.

8. Tett, P.B. The relation between dinoflagellates and the bioluminescence of sea water. J. Mar. Biol. Assoc. UK 1971, 51, 183-206.

9. Harvey, E.N. A History of Luminescence from the Earliest Times Until 1900: From the Earliest Times Until 1900; Dover Publications: Mineola, NY, USA, 1957; p. 692.

10. Lynch, R.V. The Occurence and Distribution of Surface Bioluminescence in the Oceans during 1966 through 1977; Naval Research Laboratory: Washington, DC, USA, 1978; p. 49.

11. Gomez, F. A quantitative review of the lifestyle, habitat and trophic diversity of dinoflagellates (Dinoflagellata, Alveolata). Syst. Biodivers. 2012, 10, 267-275. 
12. DeSa, R.; Hastings, J.W. The characterization of scintillons. Bioluminescent particles from the marine dinoflagellate, Gonyaulax polyedra. J. Gen. Physiol. 1968, 51, 105-122.

13. Akimoto, H.; Wu, C.; Kinumi, T.; Ohmiya, Y. Biological rhythmicity in expressed proteins of the marine dinoflagellate Lingulodinium polyedrum demonstrated by chronological proteomics. Biochem. Biophys. Res. Commun. 2004, 315, 306-312.

14. Johnson, C.H.; Inoue, S.; Flint, A.; Hastings, J.W. Compartmentalization of algal bioluminescence - autofluorescence of bioluminescent particles in the dinoflagellate Gonyaulax as studied with image-intensified video microscopy and flow cytometry. J. Cell Biol. 1985, 100, 1435-1446.

15. Knaust, R.; Urbig, T.; Li, L.M.; Taylor, W.; Hastings, J.W. The circadian rhythm of bioluminescence in Pyrocystis is not due to differences in the amount of luciferase: A comparative study of three bioluminescent marine dinoflagellates. J. Phycol. 1998, 34, 167-172.

16. Schmitter, R.E.; Njus, D.; Sulzman, F.M.; Gooch, V.D.; Hastings, J.W. Dinoflagellate bioluminescence-Comparative study of in vitro components. J. Cell. Physiol. 1976, 87, 123-134.

17. Nicolas, M.T.; Sweeney, B.M.; Hastings, J.W. The ultrastructural localization of luciferase in three bioluminescent dinoflagellates, two species of Pyrocystis, and Noctiluca, using anti-luciferase and immunogold labelling. J. Cell Sci. 1987, 87, 189-196.

18. Fritz, L.; Morse, D.; Hastings, J.W. The circadian bioluminescence rhythm of Gonyaulax is related to daily variations in the number of light-emitting organelles. J. Cell Sci. 1990, 95, 321-328.

19. Seo, K.S.; Fritz, L. Cell ultrastructural changes correlate with circadian rhythms in Pyrocystis lunula (Pyrrophyta). J. Phycol. 2000, 36, 351-358.

20. Maldonado, E.M.; Latz, M.I. Shear-stress dependence of dinoflagellate bioluminescence. Biol. Bull. 2007, 212, 242-249.

21. Latz, M.I.; Bovard, M.; VanDelinder, V.; Segre, E.; Rohr, J.; Groisman, A. Bioluminescent response of individual dinoflagellate cells to hydrodynamic stress measured with millisecond resolution in a microfluidic device. J. Exp. Biol. 2008, 211, 2865-2875.

22. Chen, A.K.; Latz, M.I.; Sobolewski, P.; Frangos, J.A. Evidence for the role of G-proteins in flow stimulation of dinoflagellate bioluminescence. Am. J. Physiol. Regul. Integr. Comp. Physiol. 2007, 292, R2020-R2027.

23. Hardie, R.C.; Raghu, P. Visual transduction in Drosophila. Nature 2001, 413, 186-193.

24. Von Dassow, P.; Latz, M.I. The role of $\mathrm{Ca}^{2+}$ in stimulated bioluminescence of the dinoflagellate Lingulodinium polyedrum. J. Exp. Biol. 2002, 205, 2971-2986.

25. Fogel, M.; Hastings, J.W. Bioluminescence-Mechanism and mode of control of scintillon activity. Proc. Natl. Acad. Sci. USA 1972, 69, 690-693.

26. Smith, S.M.E.; Morgan, D.; Musset, B.; Cherny, V.V.; Place, A.R.; Hastings, J.W.; DeCoursey, T.E. Voltage-gated proton channel in a dinoflagellate. Proc. Natl. Acad. Sci. USA 2011, 108, 18162-18167.

27. Schultz, L.W.; Liu, L.; Cegielski, M.; Hastings, J.W. Crystal structure of a pH-regulated luciferase catalyzing the bioluminescent oxidation of an open tetrapyrrole. Proc. Natl. Acad. Sci. USA 2005, 102, 1378-1383.

28. Shimomura, O. Bioluminescence: Chemical Principles and Methods; World Scientific: Singapore, Singapore, 2006; p. 470. 
29. Wilson, T.; Hastings, J. Bioluminescence: Living Lights, Lights for Living; Harvard University Press: Cambridge, MA, USA, 2013; p. 185.

30. Liu, L.Y.; Wilson, T.; Hastings, J.W. Molecular evolution of dinoflagellate luciferases, enzymes with three catalytic domains in a single polypeptide. Proc. Natl. Acad. Sci. USA 2004, 101, $16555-16560$.

31. Li, L.; Hastings, J.W. The structure and organization of the luciferase gene in the photosynthetic dinoflagellate Gonyaulax polyedra. Plant Mol. Biol. 1998, 36, 275-284.

32. Liu, L.Y.; Hastings, J.W. Two different domains of the luciferase gene in the heterotrophic dinoflagellate Noctiluca scintillans occur as two separate genes in photosynthetic species. Proc. Natl. Acad. Sci. USA 2007, 104, 696-701.

33. Li, L.; Hong, R.; Hastings, J.W. Three functional luciferase domains in a single polypeptide chain. Proc. Natl. Acad. Sci. USA 1997, 94, 8954-8958.

34. Bae, Y.; Hastings, J. Cloning, sequencing and expression of dinoflagellate luciferase DNA from a marine alga. Gonyaulax polyedra. Biochim. Biophys. Acta Gene Struct. Expr. 1994, 1219, 449-456.

35. Suzuki-Ogoh, C.; Wu, C.; Ohmiya, Y. C-terminal region of the active domain enhances enzymatic activity in dinoflagellate luciferase. Photochem. Photobiol. Sci. 2008, 7, 208-211.

36. Li, L.; Liu, L.; Hong, R.; Robertson, D.; Hastings, J.W. N-terminal intramolecularly conserved histidines of three domains in Gonylaulax luciferase are responsible for loss of activity in the alkaline region. Biochemistry 2001, 40, 1844-1849.

37. Okamoto, O.K.; Liu, L.; Robertson, D.L.; Hastings, J.W. Members of a dinoflagellate luciferase gene family differ in synonymous substitution rates. Biochemistry 2001, 40, 15862-15868.

38. Liu, L.Y.; Hastings, J.W. Novel and rapidly diverging intergenic sequences between tandem repeats of the luciferase genes in seven dinoflagellate species. J. Phycol. 2006, 42, 96-103.

39. Swift, E.; Sullivan, J.M.; Batchelder, H.P.; van Keuren, J.; Vaillancourt, R.D.; Bidigare, R.R. Bioluminescent organisms and bioluminescence measurements in the North Atlantic Ocean near latitude 59.5 N, longitude 21 W. J. Geophys. Res. Oceans 1995, 100, 6527-6547.

40. Fogel, M.; Hastings, J.W. A substrate-binding protein in the Gonyaulax bioluminescence reaction. Arch. Biochem. Biophys. 1971, 142, 310-321.

41. Erdner, D.L.; Anderson, D.M. Global transcriptional profiling of the toxic dinoflagellate Alexandrium fundyense using Massively Parallel Signature Sequencing. BMC Genomics 2006, 7, doi:10.1186/1471-2164-7-88.

42. Uribe, P.; Fuentes, D.; Valdés, J.; Shmaryahu, A.; Zúñiga, A.; Holmes, D.; Valenzuela, P.D.T. Preparation and analysis of an expressed sequence tag library from the toxic dinoflagellate Alexandrium catenella. Mar. Biotechnol. 2008, 10, 692-700.

43. Hackett, J.D.; Scheetz, T.E.; Yoon, H.S.; Soares, M.B.; Bonaldo, M.F.; Casavant, T.L.; Bhattacharya, D. Insights into a dinoflagellate genome through expressed sequence tag analysis. BMC Genomics 2005, 6, doi:10.1186/1471-2164-6-80.

44. Jaeckisch, N.; Yang, I.; Wohlrab, S.; Glöckner, G.; Kroymann, J.; Vogel, H.; Cembella, A.; John, U. Comparative genomic and transcriptomic characterization of the toxigenic marine dinoflagellate Alexandrium ostenfeldii. PLoS One 2011, 6, e28012.

45. Machabée, S.; Wall, L.; Morse, D. Expression and genomic organization of a dinoflagellate gene family. Plant Mol. Biol. 1994, 25, 23-31. 
46. Lee, D.H.; Mittag, M.; Sczekan, S.; Morse, D.; Hastings, J.W. Molecular cloning and genomic organization of a gene for luciferin-binding protein from the dinoflagellate Gonyaulax polyedra. J. Biol. Chem. 1993, 268, 8842-8850.

47. Morse, D.; Pappenheimer, A.M.; Hastings, J.W. Role of a luciferin-binding protein in the circadian bioluminescent reaction of Gonyaulax polyedra. J. Biol. Chem. 1989, 264, 11822-11826.

48. Toulza, E.; Shin, M.-S.; Blanc, G.; Audic, S.; Laabir, M.; Collos, Y.; Claverie, J.-M.; Grzebyk, D. Gene expression in proliferating cells of the dinoflagellate Alexandrium catenella (Dinophyceae). Appl. Environ. Microbiol. 2010, 76, 4521-4529.

49. Tanikawa, N.; Akimoto, H.; Ogoh, K.; Chun, W.; Ohmiya, Y. Expressed sequence tag analysis of the dinoflagellate Lingulodinium polyedrum during dark phase. Photochem. Photobiol. 2004, $80,31-35$.

50. Dunlap, J.C.; Hastings, J.W. The biological clock in Gonyaulax controls luciferase activity by regulating turnover. J. Biol. Chem. 1981, 256, 10509-10518.

51. Fukuda, Y.; Endoh, H. Phylogenetic analyses of the dinoflagellate Noctiluca scintillans based on beta-tubulin and Hsp90 genes. Eur. J. Protistol. 2008, 44, 27-33.

52. Hoppenrath, M.; Leander, B.S. Dinoflagellate phylogeny as inferred from heat shock protein 90 and ribosomal gene sequences. PLoS One 2010, 5, e13220.

53. Gomez, F.; Moreira, D.; Lopez-Garcia, P. Molecular phylogeny of noctilucoid dinoflagellates (Noctilucales, Dinophyceae). Protist 2010, 161, 466-478.

54. Orr, R.J.S.; Murray, S.A.; Stüken, A.; Rhodes, L.; Jakobsen, K.S. When naked became armored: An eight-gene phylogeny reveals monophyletic origin of theca in dinoflagellates. PLoS One 2012, 7, e50004.

55. Nakamura, H.; Kishi, Y.; Shimomura, O.; Morse, D.; Hastings, J.W. Structure of dinoflagellate luciferin and its enzymic and nonenzymic air-oxidation products. J. Am. Chem. Soc. 1989, 111, 7607-7611.

56. Wu, C.; Akimoto, H.; Ohmiya, Y. Tracer studies on dinoflagellate luciferin with $\left[{ }^{15} \mathrm{~N}\right]$-glycine and $\left[{ }^{15} \mathrm{~N}\right]$-L-glutamic acid in the dinoflagellate Pyrocystis lunula. Tetrahedron Lett. 2003, 44, 1263-1266.

57. Topalov, G.; Kishi, Y. Chlorophyll catabolism leading to the skeleton of dinoflagellate and krill luciferins: Hypothesis and model studies. Angew. Chem. 2001, 40, 3892-3894.

58. Hamman, J.P.; Seliger, H.H. The mechanical triggering of bioluminescence in marine dinoflagellates: Chemical basis. J. Cell. Physiol. 1972, 80, 397-408.

59. Yamaguchi, A.; Horiguchi, T. Culture of the heterotrophic dinoflagellate Protoperidinium crassipes (Dinophyceae) with noncellular food items. J. Phycol. 2008, 44, 1090-1092.

60. Shimomura, O. The roles of the two highly unstable components $F$ and $P$ involved in the bioluminescence of euphausiid shrimps. J. Biolumin. Chemilumin. 1995, 10, 91-101.

61. Marcinko, C.L.J.; Allen, J.T.; Poulton, A.J.; Painter, S.C.; Martin, A.P. Diurnal variations of dinoflagellate bioluminescence within the open-ocean north-east Atlantic. J. Plankton Res. 2013, 35, 177-190.

62. Marcinko, C.L.J.; Painter, S.C.; Martin, A.P.; Allen, J.T. A review of the measurement and modelling of dinoflagellate bioluminescence. Prog. Oceanogr. 2013, 109, 117-129. 
63. Guiry, M.D.; Guiry, G.M. AlgaeBase World-Wide Electronic Publication; National University of Ireland: Galway, Ireland, 2013. Available online: http://www.algaebase.org (accessed on 28 April 2013).

64. Hastings, J.W. The Gonyaulax clock at 50: Translational control of circadian expression. Cold Spring Harbor Symp. Quant. Biol. 2007, 72, 141-144.

65. Morse, D.; Milos, P.M.; Roux, E.; Hastings, J.W. Circadian regulation of bioluminescence in Gonyaulax involves translational control. Proc. Natl. Acad. Sci. USA 1989, 86, 172-176.

66. Mittag, M.; Li, L.; Hastings, J.W. The mRNA level of the circadian regulated Gonyaulax luciferase remains constant over the cycle. Chronobiol. Int. 1998, 1998, 93-98.

67. Mittag, M.; Lee, D.H.; Hastings, J.W. Circadian expression of the luciferin-binding protein correlates with the binding of a protein to the $3^{\prime}$ untranslated region of its mRNA. Proc. Natl. Acad. Sci. USA 1994, 91, 5257-5261.

68. Lapointe, M.; Morse, D. Reassessing the role of a 3'-UTR-binding translational inhibitor in regulation of circadian bioluminescence rhythm in the dinoflagellate Gonyaulax. Biol. Chem. 2008, 389, 13-19.

69. Johnson, C.H.; Roeber, J.F.; Hastings, J.W. Circadian changes in enzyme concentration account for rhythm of enzyme activity in Gonyaulax. Science 1984, 223, 1428-1430.

70. Esaias, W.E.; Curl, H.C.; Seliger, H.H. Action spectrum for a low intensity, rapid photoinhibition of mechanically stimulable bioluminescence in the marine dinoflagellates Gonyaulax catenella, G. acatenella, and G. tamarensis. J. Cell. Physiol. 1973, 82, 363-372.

71. Hamman, J.P.; Biggley, W.H.; Seliger, H.H. Action spectrum for the photoinhibition of bioluminescence in the marine dinoflagellate Dissodinium lunula. Photochem. Photobiol. 1981, $33,741-747$.

72. Hamman, J.P.; Seliger, H.H. The chemical mimicking of the mechanical stimulation, photoinhibition, and recovery from photoinhibition of bioluminescence in the marine dinoflagellate, Gonyaulax polyedra. J. Cell. Physiol. 1982, 111, 315-319.

73. Li, Y.Q.; Swift, E.; Buskey, E.J. Photoinhibition of mechanically stimulable bioluminescence in the heterotrophic dinoflagellate Protoperidinium depressum (Pyrrophyta). J. Phycol. 1996, 32, 974-982.

74. Sullivan, J.M.; Swift, E. Photoinhibition of mechanically stimulable bioluminescence in the autotrophic dinoflagellate Ceratium fusus (Pyrrophyta). J. Phycol. 1994, 30, 627-633.

75. Sweeney, B.M.; Haxo, F.T.; Hastings, J.W. Action spectra for two effects of light on luminescence in Gonyaulax polyedra. J. Gen. Physiol. 1959, 43, 285-299.

76. Buskey, E.J.; Strom, S.; Coulter, C. Biolumiscence of heterotrophic dinoflagellates from Texas coastal waters. J. Exp. Mar. Biol. Ecol. 1992, 159, 37-49.

77. Raymond, J.A.; DeVries, A.L. Bioluminescence in McMurdo Sound, Antarctica. Limnol. Oceanogr. 1976, 21, 599-602.

78. Hamman, J.P.; Biggley, W.H.; Seliger, H.H. Photoinhibition of stimulable bioluminescence in marine dinoflagellates. Photochem. Photobiol. 1981, 33, 909-914.

79. Lapota, D.; Young, D.K.; Bernstein, S.A.; Geiger, M.L.; Huddell, H.D.; Case, J.F. Diel bioluminescence in heterotrophic and photosynthetic marine dinoflagellates in an Arctic fjord. J. Mar. Biol. Assoc. UK 1992, 72, 733-744. 
80. Batchelder, H.P.; Swift, E.; Keuren, J.R. Diel patterns of planktonic bioluminescence in the northern Sargasso Sea. Mar. Biol. 1992, 113, 329-339.

81. Biggley, W.H.; Swift, E.; Buchanan, R.J.; Seliger, H.H. Stimulable and spontaneous bioluminescence in the marine dinoflagellates Pyrodinium bahamense, Gonyaulax polyedra and Pyrocystis lunula.J. Gen. Physiol. 1969, 54, 96-122.

82. Krasnow, R.; Dunlap, J.; Taylor, W.; Hastings, J.W.; Vetterling, W.; Gooch, V. Circadian spontaneous bioluminescent glow and flashing of Gonyaulax polyedra. J. Comp. Physiol. B 1980, 138, 19-26.

83. Colepicolo, P.; Roenneberg, T.; Morse, D.; Taylor, W.R.; Hastings, J.W. Circadian regulation of bioluminescence in the dinoflagellate Pyrocystis lunula. J. Phycol. 1993, 29, 173-179.

84. Latz, M.I.; Lee, A.O. Spontaneous and stimulated bioluminescence of the dinoflagellate Ceratocorys horrida (Peridiniales). J. Phycol. 1995, 31, 120-132.

85. Eckert, R. Excitation and luminescence in Noctiluca miliaris. In Bio-luminescence in Progress; Johnson, F.H., Haneda, Y., Eds; Princeton University Press: Princeton, NJ, USA, pp. 269-300.

86. Widder, E.; Case, J. Two flash forms in the bioluminescent dinoflagellate Pyrocystis fusiformis. J. Comp. Physiol. A 1981, 143, 43-52.

87. Schmidt, R.J.; Gooch, V.D.; Loeblich, A.R.; Hastings, J.W. Comparative study of luminescent and non-luminescent strains of Gonyaulax excavata (Pyrrhophyta). J. Phycol. 1978, 14, 5-9.

88. Cussatlegras, A.S.; Le Gal, P. Variability in the bioluminesence response of the dinoflagellate Pyrocystis lunula. J. Exp. Mar. Biol. Ecol. 2007, 343, 74-81.

89. Buskey, E.J.; Swift, E. An encounter model to predict natural planktonic bioluminescence. Limnol. Oceanogr. 1990, 35, 1469-1485.

90. Sweeney, B.M. Ultrastructure of Noctiluca miliaris (Pyrrophyta) with green flagellate symbionts. J. Phycol. 1978, 14, 116-120.

91. Eckert, R.; Reynolds, G. The subcellular origin of bioluminescence in Noctiluca miliaris. J. Gen. Physiol. 1967, 50, 1429-1458.

92. Latz, M.I.; Case, J.F.; Gran, R.L. Excitation of bioluminescence by laminar fluid shear associated with simple Couette flow. Limnol. Oceanogr. 1994, 39, 1424-1439.

93. von Dassow, P.; Bearon, R.N.; Latz, M.I. Bioluminescent response of the dinoflagellate Lingulodinium polyedrum to developing flow: Tuning of sensitivity and the role of desensitization in controlling a defensive behaviour of a planktonic cell. Limnol. Oceanogr. 2005, 50, 607-619.

94. Sweeney, B.M. The loss of the circadian rhythm in photosynthesis in an old strain of Gonyaulax polyedra. Plant Physiol. 1986, 80, 978-981.

95. Dickson, I. Bioluminescent Organelle Changes in Four Species of Dinoflagellates Using Confocal Laser Scanning Microscopy. MRes Dissertation, University of Southampton, Southampton, UK, 2008.

96. Swift, E.; Biggley, W.H.; Seliger, H.H. Species of oceanic dinoflagellates in genera Dissodinium and Pyrocystis-Interclonal and interspecific comparisons of color and photon yield of bioluminescence. J. Phycol. 1973, 9, 420-426.

97. Buskey, E.J.; Coulter, C.J.; Brown, S.L. Feeding, growth and bioluminescence of the heterotrophic dinoflagellate Protoperidinium huberi. Mar. Biol. 1994, 121, 373-380. 
98. Sweeney, B.M. Variations of the Bioluminescence per Cell in Dinoflagellates. In Bioluminescence Current Perspectives; Nealson, K.H., Ed.; Burgess Publishing: Minneapolis, MN, USA, 1981; pp. 90-94.

99. Latz, M.I.; Jeong, H.J. Effect of red tide dinoflagellate diet and cannibalism on the bioluminescence of the heterotrophic dinoflagellates Protoperidinium spp. Mar. Ecol. Prog. Ser. 1996, 132, 275-285.

100. Sullivan, J.M.; Swift, E. Photoenhancement of bioluminescence capacity in natural and laboratory populations of the autotrophic dinoflagellate Ceratium fusus (Ehrenb.) Dujardin. J. Geophys. Res. Oceans 1995, 100, 6565-6574.

101. Esaias, W.E.; Curl, H.C. Effect of dinoflagellate bioluminescence on copepod ingestion rates. Limnol. Oceanogr. 1972, 17, 901-905.

102. White, H.H. Effects of dinoflagellate bioluminescence on the ingestion rates of herbivorous zooplankton. J. Exp. Mar. Biol. Ecol. 1979, 36, 217-224.

103. Buskey, E.; Mills, L.; Swift, E. The effects of dinoflagellate bioluminescence on the swimming behavior of a marine copepod. Limnol. Oceanogr. 1983, 28, 575-579.

104. Buskey, E.J.; Mann, C.G.; Swift, E. Photophobic responses of calanoid copepods: Possible adaptive value. J. Plankton Res. 1987, 9, 857-870.

105. Buskey, E.J.; Swift, E. Behavioral responses of oceanic zooplankton to simulated bioluminescence. Biol. Bull. 1985, 168, 263-275.

106. Burkenroad, M.D. A possible function of bioluminescence. J. Mar. Res. 1943, 5, 161-164.

107. Abrahams, M.V.; Townsend, L.D. Bioluminescence in dinoflgellates: A test of the burgular alarm hypothesis. Ecology 1993, 74, 258-260.

108. Mesinger, A.F.; Case, J.F. Dinoflagellate luminescence increases susceptibility of zooplankton to teleost predation. Mar. Biol. 1992, 112, 207-210.

109. Swift, E.; Lessard, E.J.; Biggley, W.H. Organisms associated with stimulated epipelagic bioluminescence in the Sargasso Sea and the Gulf Stream. J. Plankton Res. 1985, 7, 831-848.

110. Latz, M.I.; Frank, T.M.; Case, J.F. Spectral composition of bioluminescence of epipelagic organisms from the Sargasso Sea. Mar. Biol. 1988, 98, 441-446.

111. Neilson, D.J.; Latz, M.I.; Case, J.F. Temporal variability in the vertical structure of bioluminescence in the North Atlantic Ocean. J. Geophys. Res. Oceans 1995, 100, 6591-6603.

112. Baker, A.; Robbins, I.; Moline, M.A.; Iglesias-Rodriguez, M.D. Oligonucleotide primers for the detection of bioluminescent dinoflagellates reveal novel luciferase sequences and information on the molecular evolution of this gene. J. Phycol. 2008, 44, 419-428.

(C) 2013 by the authors; licensee MDPI, Basel, Switzerland. This article is an open access article distributed under the terms and conditions of the Creative Commons Attribution license (http://creativecommons.org/licenses/by/3.0/). 